\title{
Representasi Perilaku Toleran dalam Puisi Karya Siswa SMA
}

\author{
Abdul Karim Wirawan ${ }^{1}$, Muakibatul Hasanah ${ }^{1}$, Maryaeni ${ }^{1}$ \\ ${ }^{1}$ Pendidikan Bahasa Indonesia-Universitas Negeri Malang
}

\section{INFO ARTIKEL}

\section{Riwayat Artikel:}

Diterima: 27-12-2019

Disetujui: $14-07-2020$

\section{Kata kunci:}

representations of tolerant behavior;

poetry;

high school student

representasi perilaku toleran;

puisi;

siswa SMA

\section{ABSTRAK}

Abstract: This study aims to describe the tolerant behavior contained in poems by high school students. This research uses a qualitative approach based on the theory of sociological literature. The results showed that tolerant behavior contained in poems by students in the form of (1) respecting others, (2) accepting and valuing differences, (3) being open to others, and (4) accepting differences of opinion. Tolerant behavior in poetry high school students tends to be aimed at the closest people, namely mothers and friends. Tolerant behavior is also aimed not only at fellow human beings but also at other living things.

\begin{abstract}
Abstrak: Penelitian ini bertujuan untuk mendeskripsikan perilaku toleran yang terdapat dalam puisi karya siswa SMA. Penelitian ini menggunakan pendekatan kualitatif berdasarkan teori sosiologi sastra. Hasil penelitian menunjukkan bahwa perilaku toleran yang terdapat dalam puisi karya siswa berupa (1) menghargai orang lain, (2) menerima dan menghargai perbedaan, (3) bersikap terbuka terhadap orang lain, dan (4) menerima perbedaan pendapat. Perilaku toleran dalam puisi karya siswa SMA cenderung ditujukan kepada orang terdekat, yakni ibu dan sahabat. Perilaku toleran juga ditujukan tidak hanya kepada sesama manusia, namun juga kepada makhluk hidup lain.
\end{abstract}

\author{
Alamat Korespondensi: \\ Abdul Karim Wirawan \\ Pendidikan Bahasa Indonesia \\ Universitas Negeri Malang \\ Jalan Semarang 5 Malang \\ E-mail: abdulkarimwira@gmail.com
}

Karya sastra selalu tidak dapat dipisahkan dari masyarakat yang berada di sekitarnya. Karya sastra selalu memengaruhi dan dipengaruhi oleh masyarakatnya, meskipun wujud sastra secara konkret adalah berupa teks. Sastra selalu diikuti dan mengikuti masyarakat tempat karya sastra tersebut berada. Karya sastra juga memengaruhi masyarakat pembacanya, sebagaimana masyarakat juga yang memengaruhi proses pembuatan karya sastra itu. Fakta ini menunjukkan bahwa karya sastra dan masyarakat yang mengelilinginya tidak dapat dipisahkan. Fakta ini pula yang memunculkan teori sosiologi sastra. Konsep sosiologi sastra adalah bahwa karya sastra tidak akan lepas dari masyarakatnya (Endraswara, 2011). Sosiologi sastra adalah aktivitas pemahaman dalam rangka mengungkapkan aspek-aspek kemasyarakatan yang terkandung dalam karya sastra (Ratna, 2012). Hal utama yang dipelajari dalam sosiologi sastra ada dua hal, yakni konteks pengarang dan konteks sastra sebagai cerminan masyarakat (Endraswara, 2011).

Sastra telah menjadi potret sosial dalam masyarakat. Karya sastra menjadi gambaran rekaan seseorang yang diwarnai oleh sikap, latar belakang, serta keyakinan pengarang (Mabruri \& Sayuti, 2015). Sastra merupakan potret gejala sosial. Karya sastra merefleksikan apa yang terjadi di dalam masyarakat tersebut dalam kurun waktu dan zaman tertentu. Untuk dapat merefleksikan keadaan masyarakat, pengarang sastra harus dekat dengan masyarakat itu (Sumiyardana, 2018). Oleh karena itu, tidak mengherankan jika banyak tokoh yang mengemukakan pendapat tentang eratnya keterkaitan antara sastra, pengarang, dan masyarakatnya.

Dalam kaitan antara sastra dan masyarakat, terdapat pula garis batas yang jelas antara sastra dan realita. Sejauh apapun sebuah karya sastra merepresentasikan masyarakatnya, ia tetap merupakan sebuah karya fiksi yang terlepas dari kenyataan. Oleh karena itu, karya sastra terkadang tidak merefleksikan kenyataan, melainkan membiaskan, bahkan mungkin mengubahnya sehingga menjadi bentuk yang berlainan. Dunia yang diciptakan dalam sastra adalah dunia alternatif dan alternatif terhadap kenyataan hanya dapat dibayangkan sesuai dengan penafsiran kenyataan tersebut (Teeuw, 2013). Untuk dapat mengembalikan ke bentuk asli, perlu dilakukan proses interpretasi. Interpretasi sosiologi sastra mengaitkan estetika dengan fungsi-fungsi sosial sastra. Hal ini membuat munculnya istilah kebenaran nyata dan kebenaran sastra.

Kajian puisi secara ilmiah diperlukan untuk memenuhi kebutuhan akan bentuk-bentuk analisis puisi yang objektif dan dapat dipertanggungjawabkan serta diperiksa ulang keabsahannya (Hasanah, 2014). Penelitian ini mengkaji perilaku toleran yang terdapat dalam puisi. Puisi dipilih karena puisi adalah bentuk karya sastra yang mengungkapkan pikiran dan perasaan penyair secara imajinatif dan disusun dengan mengonsentrasikan semua kekuatan bahasa dengan pengonsentrasian struktur fisik 
dan struktur batinnya (Waluyo). Puisi adalah ungkapan pikir dan rasa yang padat dan berirama, dalam bentuk larik dan bait dengan memakai bahasa indah dalam koridor estetik (Tjahjono, 2011). Puisi merupakan sebuah bentuk karya sastra yang menonjolkan bait dan larik sebagai penanda kebahasaan (Wirawan, 2019b). Penggunaan unsur kebahasaan ini menjadi hal yang penting dalam puisi dan membuat puisi tersebut memiliki ciri khasnya sendiri (Wilson \& Dymoke, 2017). Namun demikian, Puisi bukan hanya berurusan dengan bentuk ekspresi dan isi, namun juga aksi, yaitu bagaimana puisi mampu terlibat membangun penyadaran bagi masyarakat tentang persoalan hidup mereka (Tjahjono, 2012).

Bentuk perilaku toleran, meliputi (1) menghargai orang lain, (2) menerima dan menghargai perbedaan, (3) bersikap terbuka terhadap orang lain, dan (4) menerima perbedaan pendapat. Toleransi dapat dimaknai dengan membangun kehidupan damai (peaceful coexistence) di antara berbagai kelompok masyarakat dari berbagai perbedaan latar belakang sejarah, kebudayaan dan identitas (Misrawi, 2006). Dalam bertoleransi, manusia harus mengesampingkan berbagai perbedaan yang melekat dalam diri masing-masing individu. konsep utama toleransi adalah saling mengizinkan atau saling memudahkan (Ghazali, 2009). Penggunaan kata saling pada konsep tersebut menegaskan bahwa hubungan toleransi bersifat timbal balik. Bertoleransi tidak hanya dilakukan oleh satu pihak saja, melainkan butuh dari kedua belah pihak. Istilah toleransi dalam konsep ini mengadaptasi istilah dalam Al Quran, yakni At-Tasammuh. Pengadaptasian dari Al-Quran membuat konsep ini selaras dengan konsep keislaman. Agama Islam menekankan pada perilaku yang tidak diskriminatif, berlaku adil, serta saling memahami antar-manusia. Hal ini karena manusia diciptakan berbeda-beda suku, bangsa, ras, warna kulit, agar manusia saling memahami dan saling mengenal. Hal ini merupakan sikap penghargaan terhadap kemajemukan (Efendi, 1994).

\section{METODE}

Penelitian ini menggunakan pendekatan kualitatif dengan jenis penelitian berupa studi teks. Penelitian ini disebut penelitian kualitatif karena sesuai dengan ciri-ciri penelitian kualitatif serta memaparkan data berupa deskripsi perilaku toleran dalam puisi siswa. Ciri penelitian kualitatif yang sesuai dengan penelitian ini adalah peneliti sebagai instrumen kunci, meneliti pada kondisi objek yang alami tanpa ada perlakuan, menggunakan metode analisis data induktif, serta berdasarkan teori (Creswell, 2009). Teks yang dianalisis dalam penelitian ini adalah puisi karya siswa SMA Kabupaten Gresik menggunakan teori sosiologi sastra.

Tahapan pengumpulan data dalam penelitian ini dapat disusun dengan urutan (1) menghimpun puisi karya siswa SMA Kabupaten Gresik, (2) menyusun kisi-kisi panduan analisis perilaku toleran dalam puisi karya siswa, (3) menyusun aspek, deskripsi, dan indikator perilaku toleran sebagai alat bantu pengumpulan data, (4) melakukan seleksi puisi karya siswa yang akan dijadikan data penelitian berdasarkan indikator yang telah disusun, (5) mengidentifikasi dan menandai perilaku toleran dalam puisi dengan menandai larik atau bait puisi, dan (6) melakukan koreksi hasil identifikasi perilaku toleran dalam puisi.

Analisis data dalam penelitian ini memiliki tahapan yang terperinci mengadaptasi langkah analisis data menurut Creswell yang dibagi ke dalam enam spesifik, yakni mempersiapkan data, menemukan makna umum, memulai kodifikasi, mendeskripsikan, mendeskripsikan data, dan membuat interpretasi (Creswell, 2009). Berdasarkan tahapan tersebut, langkah analisis data penelitian ini dibagi ke dalam tahapan-tahapan spesifik, yakni (1) mempersiapkan data puisi karya siswa, (2) melakukan seleksi data puisi yang akan dianalisis, (3) membaca dengan cermat dan saksama puisi karya siswa, (4) mengidentifikasi larik puisi siswa yang merepresentasikan perilaku toleran melalui majas dan sarana retorika, (5) mengklasifikasi data berdasarkan instrumen pengumpulan dan analisis data yang telah dibuat, (6) melakukan uji keabsahan data dan reduksi data, (7) memasukkan data hasil reduksi ke dalam korpus data, (8) melakukan kodifikasi data representasi perilaku toleran dalam puisi karya siswa, (9) melakukan penyajian data perilaku toleran dalam puisi karya siswa, (10) mengaitkan data dengan teori toleransi, (11) melakukan koreksi hasil interpretasi perilaku toleran dalam puisi karya siswa, dan (12) melakukan penyimpulan akhir berdasarkan hasil koreksi.

Upaya menjaga keabsahan temuan dalam penelitian dilakukan dengan trustworthiness yang terdiri atas empat langkah, yakni (1) kredibilitas, (2) transferabilitas, (3) dependabilitas, dan (4) konfirmabilitas (Lincoln \& Guba, 1985). Kredibilitas adalah upaya peneliti menjaga kesesuaian hasil penelitian dengan fakta di lapangan. Upaya ini dapat dilakukan dengan memberi check, perpanjangan waktu penelitian, diskusi dengan teman sejawat, serta pengoptimalan pengumpulan data mentah. Transferabilitas berkaitan dengan pertanggungjawaban peneliti kepada pembaca bahwa kumpulan informasi-dalam suatu kasus yang diteliti dapat diterapkan dalam kasus yang sama. Dependabilitas adalah tanggung jawab peneliti terhadap keandalan hasil penelitian. Konfirmabilitas adalah pembangunan fakta, pemrosesan data, dan penginterpretasian data oleh peneliti. Seluruh proses tersebut harus disajikan secara deskriptif dan sesuai fakta, bukan hanya sekadar opini peneliti.

\section{HASIL}

Berdasarkan hasil analisis data, terdapat 18 data perilaku toleran dalam puisi karya siswa SMA Kabupaten Gresik, meliputi menghargai orang lain, menerima dan menghargai perbedaan, bersikap terbuka terhadap orang lain, serta menerima perbedaan pendapat. Persebaran data perilaku toleran ini dapat dilihat pada tabel 1. 


\section{Tabel 1. Persebaran Data Perilaku Toleran}

\begin{tabular}{lc}
\hline \multicolumn{1}{c}{ Bentuk Perilaku toleran } & Jumlah Data \\
\hline Menghargai orang lain & 10 \\
Menerima dan menghargai perbedaan & 1 \\
Bersikap terbuka terhadap orang lain & 4 \\
Menerima perbedaan pendapat & 3 \\
\hline
\end{tabular}

Tabel 1 menunjukkan bahwa bentuk perilaku toleran yang paling banyak muncul dalam puisi karya siswa SMA Kabupaten Gresik adalah menghargai orang lain. Bentuk perilaku toleran ini muncul sebanyak 10 kali, yang dapat dilihat dalam kutipan (1), (2) dan (3).

(1) Ibu... engkau bagaikan malaikat nyataku Engkau selalu ada di setiap langkahku Bagaikan wanita terhebatku (P1/Kons/Tol/D01)

(2) Ibu...

Kau adalah wanita yang kuat

Kau tanpa rasa lelah merawatku hingga aku besar (P9/Kons/Tol/D04)

(3) Oh ibu...

Kau adalah wanita terhebat yang ada di dunia

Terima kasih atas jasamu ibu

Aku sangat menyayangimu

(P9/Kons/Tol/D05)

Pada kutipan (1) aku lirik mengibaratkan sosok ibu sebagai malaikat serta wanita terhebat. Hal ini menunjukkan sebuah penghargaan pada sosok ibu. Sosok ibu digambarkan sebagai sosok yang hebat hingga diibaratkan sebagai malaikat. Hal ini merupakan bentuk dari majas simile yang digunakan oleh penulis dalam menggambarkan sosok ibu. Penggunaan majas ini ditandai dengan kata bagaikan yang digunakan untuk membandingkan sosok ibu dengan malaikat.

Pada kutipan (2) sosok ibu digambarkan sebagai sosok yang tanpa lelah dalam membesarkan dan membesarkan anak. Pada kutipan tersebut tercermin sebuah penghargaan pada sosok ibu yang dinyatakan dengan gaya bahasa berupa majas metafora. Metafora dalam kutipan (2) berupa perumpamaan tak pernah lelah untuk mendeskripsikan betapa besar jasa seorang ibu. Aku lirik menganggap bahwa perjuangan ibu ini membuatnya menjadi wanita yang kuat. Dalam kutipan ini aku lirik seolah-olah ikut merasakan perjuangan seorang ibu dalam merawat anaknya.

Kutipan (3) menggambarkan rasa terima kasih aku lirik pada sosok ibu. Hal ini karena menurut aku lirik, jasa seorang ibu sangat besar. Sosok ibu juga digambarkan sebagai sosok yang paling hebat di dunia. Dalam kutipan ini aku lirik menunjukkan rasa terima kasih dan penghargaan kepada sosok ibu dengan menyebut sosok ibu sebagai wanita terhebat yang ada di dunia. Penggambaran ini merupakan bentuk sarana retorika berupa hiperbola. Hal ini karena sosok ibu dalam kutipan tersebut disebutkan sebagai wanita terhebat di dunia. Penyebutan ini menunjukkan bahwa aku lirik ingin mengesankan betapa besarnya peran ibu dalam kehidupannya. Kutipan (4) dan (5) masih merupakan bentuk perilaku toleran berupa menghargai orang lain yang ditujukan kepada sosok ibu.

(4) Di setiap langkahku

Ada perjuanganmu

Di setiap kesuksesanku

Ada doa mu

(P12/Kons/Tol/D08)

(5) Terima kasih atas doamu yang

Selalu menyertaiku

Kesabaran, kasih sayang dan

Pengorbanan yang kau berikan

Kepadaku

(P12/Kons/Tol/D09)

Pada kutipan (4) digambarkan bahwa kesuksesan seorang anak tak lepas dari campur tangan sang Ibu. Ibu selalu mendoakan dan memperjuangkan kesuksesan anaknya. Dalam kutipan (4) dipakai diksi di setiap langkahku ada perjuanganmu untuk menegaskan peran penting Ibu dalam kehidupan anaknya. Kutipan (4) mengandung majas metafora. Majas ini digunakan untuk mempertegas makna perjuangan seorang Ibu yang ingin ditonjolkan oleh penulis. 
Kutipan (5) mendeskripsikan rasa terima kasih aku lirik kepada sosok Ibu atas jasa Ibu. Hal ini menunjukkan bentuk penghargaan aku lirik sebagai seorang anak kepada Ibu. Sosok ibu digambarkan sebagai sosok yang sabar, penuh kasih sayang, dan rela berkorban. Gaya penggambaran ini merupakan gaya sarana retorika berupa klimaks. Puncak penghargaan kepada Ibu oleh aku lirik adalah dengan menyebut Ibu sosok yang rela berkorban.

Ibu merupakan tema yang paling banyak dipilih untuk dijadikan puisi oleh siswa SMA Kabupaten Gresik. Hal ini karena Ibu merupakan elemen utama dalam perkembangan anak. Sosok Ibu berperan penting dalam setiap fase kehidupan anak, mulai pra-kelahiran, kelahiran, masa bayi, anak-anak, remaja hingga dewasa. Tidak ada fase yang tidak dilalui tanpa campur tangan seorang Ibu.

(6) Ibu...

Kaulah wanita yang sempurna

Yang selalu ada dalam suka dan duka

Oh... ibu

Kaulah bidadari surgaku

(P14/Kons/Tol/D10)

(7) Karena sekarang

Aku sudah besar

Dan badanmu tidak mungkin kuat

Untuk menggendongku kembali

(P20/Kons/Tol/D13)

Pada kutipan (6) terdapat penghargaan pada Ibu oleh aku lirik berupa penyebutan wanita yang sempurna. Pada kutipan tersebut sosok ibu digambarkan sebagai seseorang yang sempurna dan tanpa celah. Hal ini merupakan gaya hiperbola yang digunakan untuk memuji sosok Ibu. Gaya ini digunakan untuk menonjolkan sosok Ibu yang telah berjasa terhadap aku lirik.

Kutipan (7) mendeskripsikan penghargaan kepada Ibu atas jerih payahnya membesarkan anak. Aku lirik menggambarkan bahwa dirinya kini telah besar (dewasa) sehingga sang Ibu tidak mungkin kuat untuk menggendongnya. Penggambaran ini bermakna dua hal. Pertama, Ibu dalam penggambaran aku lirik adalah seorang yang sangat menyayangi anaknya. Hal ini ditandai dengan diksi menggendong untuk menjelaskan kasih sayang Ibu kepada anak. Kedua, kasih sayang ibu tersebut masih tetap hingga sang anak tumbuh dewasa, sehingga sang anak berkeinginan untuk membalas kasih sayang Ibu tersebut. Bentuk perilaku toleran berupa menghargai orang lain dalam puisi karya siswa SMA Kabupaten Gresik tidak hanya terbatas pada sesama manusia, melainkan juga kepada makhluk hidup lain. Hal ini dapat dilihat dalam Kutipan (8), (9), dan (10).

(8) Tidakkah kau tahu buah yang kamu makan

Adalah hasil dari penyerbukanku

Apa jasamu buat diriku

(P2/Kons/Tol/D02)

(9) Karenamu hidup ini berwarna Karenamu kami bisa hidup (P10/Kons/Tol/D06)

(10) Di balik semua tertanam jasa Daur ulang hasil tugasnya Pikir-pikir boleh juga

Seandainya tak ada lalat apa jadinya

(P15/Kons/Tol/D11)

Kutipan (8) di atas menunjukkan bentuk perilaku toleran pada binatang kumbang. Kumbang digambarkan sebagai binatang yang memiliki sengat serta sering melubangi kayu rumah. Hal ini tentu menimbulkan kejengkelan kepada kumbang. Namun demikian, kumbang juga memiliki jasa di dalam lingkungan. Salah satu jasa kumbang adalah agen penyerbukan tanaman. Jasa ini sangat penting bagi kelangsungan ekosistem. Pentingnya peran kumbang dalam puisi ini ditonjolkan dengan penggunaan sarana retorika berupa pertanyaan retoris. Pengarang ingin menegaskan bahwa keberadaan kumbang tidak semata mengganggu, melainkan memiliki peran yang penting dalam kehidupan.

Kutipan (9) menunjukkan pentingnya peran pohon dalam keberlangsungan kehidupan. Aku lirik menggambarkan bahwa pohonlah yang membuat ia hidup. Hal ini menunjukkan pentingnya pohon bagi kehidupan. Dalam kutipan tersebut juga ditonjolkan penggunaan sarana retorika berupa pertanyaan retoris. Hal ini untuk menegaskan maksud penulis bahwa tanpa adanya pohon, manusia tidak dapat hidup. Tanpa adanya pohon, penulis tidak dapat membayangkan kekacauan yang akan terjadi.

Pada kutipan (10), terdapat bentuk perilaku toleran antara manusia dengan lalat. Lalat yang digambarkan sebagai binatang jorok dan sumber penyakit sebenarnya memiliki peran yang besar di lingkungan. Lalat berfungsi untuk membusukkan berbagai jasad makhluk hidup yang telah mati. Oleh karena itu, manusia perlu menghargai lalat dan tidak memandang remeh lalat. 
Bentuk perilaku toleran berikutnya yang muncul dalam puisi karya siswa SMA Kabupaten Gresik adalah menerima dan menghargai perbedaan. Berdasarkan hasil analisis data, hanya ditemukan satu bentuk perilaku toleran berupa menerima dan menghargai perbedaan yang dapat dilihat dalam kutipan (11).

(11) Berteman denganmu kutakkan pernah takut Karena kau dapat menerima segala kekuranganku (P4/Kons/Tol/D03)

Dalam kutipan (11) perilaku perilaku toleran berupa kenyamanan aku lirik ketika bersama teman. Kenyamanan ini didapat karena sang teman dapat menerima kekurangan aku lirik. Masing-masing individu telah mampu menerima dan menghargai perbedaan yang ada pada diri masing-masing. Sikap ini membuat aku lirik tidak merasa takut berada dekat dengan teman tersebut. Sikap ini merupakan cerminan perilaku perilaku toleran berupa menerima dan menghargai perbedaan. Setiap manusia memang diciptakan berbeda, dan pasti tidak terlepas dari kesalahan. Bersikap toleran dengan menerima kekurangan orang lain dapat menjadikan hubungan semakin harmonis. Bersikap terbuka terhadap orang lain merupakan bentuk perilaku toleran ketiga yang muncul dalam puisi karya siswa SMA Kabupaten Gresik. Bentuk perilaku toleran ini muncul sebanyak empat kali, seperti dalam kutipan (12), (13), (14), dan (15).

(12) Engkau adalah orang yang sangat aku sayangi

Yang bisa membuatku tenang saat di pelukanmu

Berada di sampingmu seperti tidak ada beban di dalam hidupku

Bersamamu aku sangat merasakan kasih sayang dan ketulusan

(P11/Kons/Tol/D07)

(13) Tapi saat aku bertemu mereka

Aku merasa kota ini penuh warna

Mereka bilang "ayo kita berteman"

(P21/Kons/Tol/D14)

Pada kutipan (12) digambarkan bahwa sosok ibu adalah pengayom. Ibu selalu dapat memberikan rasa nyaman bagi aku lirik. Rasa nyaman berada dalam lindungan Ibu akan melahirkan keterbukaan. Kenyamanan berada di samping ibu tersebut dijelaskan oleh aku lirik dengan seperti tidak ada beban. Hal ini termasuk ke dalam klasifikasi gaya bahasa berupa majas simile yang ditandai dengan kata seperti. Penggunaan majas ini mengesankan bahwa aku lirik tidak memiliki beban ketika berada di samping sosok ibu. Artinya, sosok ibu ini dapat menjadi pelindung dan pengayom bagi aku lirik.

Kutipan (13) di atas mendeskripsikan bentuk keterbukaan terhadap orang lain ketika menjalin pertemanan. Sikap keterbukaan ini penting dimiliki ketika berusaha menjalin hubungan dengan orang yang baru dikenal. Tanpa sikap keterbukaan, mustahil hubungan bisa berlangsung. Hal inilah yang dirasakan oleh aku lirik ketika berusaha menjalin pertemanan. Ia berusaha terbuka dengan teman baru sehingga tempat yang ia tinggali penuh warna. Diksi penuh warna ini merupakan metafora yang digunakan untuk menjelaskan kebahagiaan aku lirik ketika berada di tempat baru dan telah memiliki teman. Kutipan (14) dan (15) masih merupakan bentuk perilaku toleran berupa sikap terbuka terhadap orang lain. Keterbukaan ini diwujudkan dengan pujian dan rasa terima kasih.

(14) Engkau yang telah melengkapi hatiku Hati yang telah lama merindu (P22/Kons/Tol/D15)

(15) Terima kasih Telah hadir dihidupku

Terima kasih

Atas penjagaan yang telah kau lakukan (P23/Kons/Tol/D17)

Kutipan (14) mendeskripsikan perasaan aku lirik ketika dalam keadaan rindu kemudian rindu tersebut terbayar. Kelegaan atas terbayarnya rasa rindu ini dinyatakan dengan metafora melengkapi hatiku. Aku lirik seolah-olah menyatakan bahwa dalam hatinya sebelumnya ada yang tidak lengkap, namun menjadi lengkap dengan kehadiran orang yang ia rindukan. Hal ini merupakan wujud keterbukaan dalam menerima kehadiran orang lain dalam hidup.

Dalam kutipan (15), dijelaskan bahwa aku lirik mengucapkan terima kasih atas penjagaan yang dilakukan oleh seseorang. Rasa terima kasih ini sangat ditonjolkan dalam kutipan tersebut sehingga perlu dinyatakan dengan gaya anafora. Ucapan terima kasih oleh aku lirik tersebut diulang sebanyak dua kali pada awal kalimat untuk menunjukkan bahwa hal itu merupakan bagian yang dipentingkan dan ditonjolkan. Bentuk perilaku toleran terakhir yang muncul dalam puisi karya siswa SMA Kabupaten Gresik adalah menerima perbedaan pendapat. Bentuk perilaku toleran ini muncul sebanyak tiga kali, seperti dalam kutipan (16), (17), dan (18). 
(16) Jadi wajar kamu sering melihat ke arahnya Ketimbang aku

Aku hanyalah salah satu dari berjuta bintang

Di sekitarmu (P19/Kons/Tol/D12)

(17) Karna aku yang menyayangimu tanpa mau tahu Apakah kau hirau akan hatiku (P22/Kons/Tol/D16)

(18) Jikapun bukan...
Tak mengapa, aku percaya takdir-Nya adalah yang terbaik
Terbaik untukku...
Dan...
Terbaik untukmu
(P24/Kons/Tol/D18)

Kutipan (16) menjelaskan tentang ketidaksetujuan aku lirik terhadap seseorang yang lebih banyak melihat ke arah orang lain daripada ke arah aku lirik. Namun demikian, dalam ketidaksetujuan ini muncul sebuah bentuk perilaku toleran berupa menerima perbedaan pendapat. Aku lirik tidak memaksakan pendapat orang lain harus sama dengan pendapatnya, namun ia menerima perbedaan pendapat tersebut meskipun mengecewakan aku lirik.

Pada kutipan (17) dijelaskan bahwa aku lirik menunjukkan rasa sayangnya kepada seseorang. Namun demikian, aku lirik tidak mengharapkan orang yang ia sayangi tersebut berbalik menyayanginya. Aku lirik bahkan tidak memedulikan apa perasaan orang yang ia sayangi tersebut. Hal ini merupakan bentuk penerimaan oleh aku lirik terhadap kemungkinan perbedaan pendapat antara dirinya dengan orang yang ia sayangi.

Kutipan (18) menjelaskan kepasrahan aku lirik terhadap takdir Tuhan. Ia menganggap dan percaya bahwa takdir Tuhan adalah yang terbaik sehingga harus diterima. Penerimaan takdir ini pun bersifat absolut, tanpa memandang takdir tersebut sesuai atau tidak dengan keinginan aku lirik. Hal ini merupakan wujud perilaku toleran aku lirik berupa menerima perbedaan pendapat. Penerimaan perbedaan pendapat ini ditandai dengan pengulangan kata terbaik sebanyak tiga kali. Hal ini menunjukkan bahwa aku lirik menerima segala takdir Tuhan, apapun bentuknya.

Berdasarkan paparan data, terdapat dominasi perilaku toleran ditujukan kepada Ibu. Perilaku toleran dalam puisi karya siswa SMA Kabupaten Gresik juga ditujukan kepada sahabat, orang yang disukai, bahkan kepada makhluk hidup lain. Hal ini dapat dilihat dalam gambar 1 .

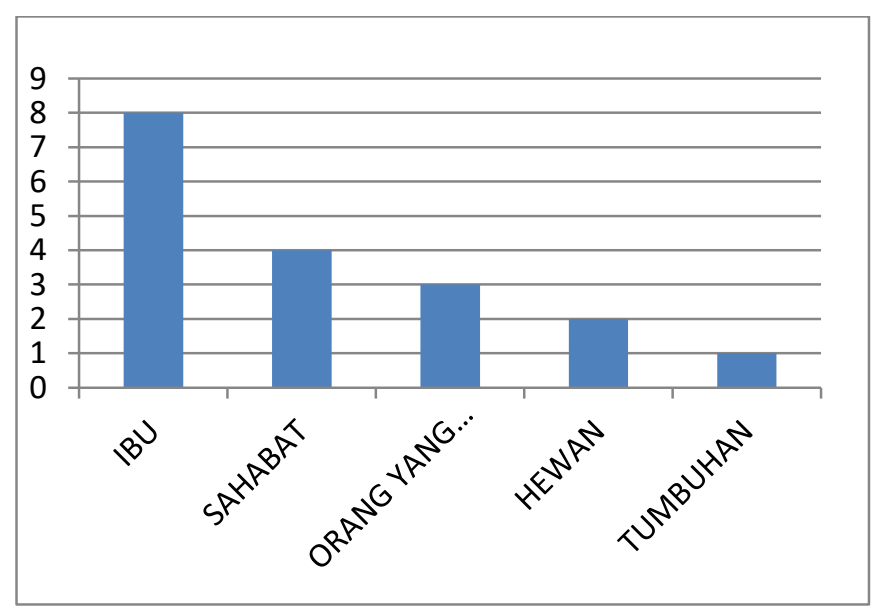

Gambar 1. Distribusi Objek Perilaku Toleran

\section{PEMBAHASAN}

Tabel 1 menunjukkan bahwa dari 18 data perilaku toleran, 10 data di antaranya berupa menghargai orang lain. Hal ini menunjukkan bahwa dalam puisi karya siswa SMA Kabupaten Gresik rasa menghargai antara satu individu dengan individu lain sangat tinggi. Perilaku menghargai orang lain dalam puisi karya siswa SMA Kabupaten Gresik banyak ditujukan kepada orang terdekat, terutama Ibu. Ibu merupakan tema favorit yang dipilih sebagai sumber inspirasi penulisan puisi. Hal ini tidak mengherankan sebab Ibu merupakan orang terdekat bagi seseorang. Ibu merupakan elemen utama dalam perkembangan anak. Sosok Ibu berperan penting dalam setiap fase kehidupan anak, mulai pra-kelahiran, kelahiran, masa bayi, anak-anak, remaja, hingga dewasa. Tidak ada fase yang tidak dilalui tanpa campur tangan seorang Ibu. 
Fakta yang ditemukan dalam puisi karya siswa SMA Kabupaten Gresik adalah perilaku toleran dominan dilakukan pada orang terdekat, yakni Ibu dan sahabat. Puisi karya siswa SMA Kabupaten Gresik belum cukup merepresentasikan perilaku toleran dalam lingkup yang lebih luas. Dalam puisi karya siswa SMA Kabupaten Gresik banyak ditemui data berupa perilaku toleran kepada Ibu. Toleransi mencakup berbagai hal, mulai dari toleransi dalam urusan peribadatan, toleransi antar-umat beragama, serta toleransi dalam masyarakat (Yasir, 2014). Cakupan perilaku toleran ini mengindikasikan bahwa bertoleransi tidak cukup hanya dengan orang-orang terdekat saja. Toleransi juga perlu dilakukan pada lingkup yang lebih luas.

Perilaku toleran pada lingkup yang luas sangat penting dilakukan di Indonesia. Hal ini karena sikap toleransi tidak dapat berdiri sendiri, melainkan dipengaruhi oleh faktor-faktor lain seperti politik, sosial, dan ekonomi. Indonesia yang dihuni oleh masyarakat dengan keragaman latar belakang agama, etnis, dan kelompok-kelompok sosial tidak dapat meninggalkan kemajemukan sebagai realitas kehidupannya (Arifin, 2016). Perilaku toleran mutlak dibutuhkan dalam kehidupan bermasyarakat di Indonesia, lebih-lebih kehidupan beragama.

Toleransi beragama di Indonesia sedang mengalami masa krisis. Hal ini disebabkan oleh perilaku eksklusivitas dari masing-masing pemeluk agama. Kompleksitas permasalahan toleransi beragama di Indonesia semakin bertambah ketika pemeluk agama yang sama pun tidak dapat bertoleransi. Masing-masing kelompok mengklaim diri sebagai kelompok yang benar, lantas memvonis salah pada kelompok yang tidak sejalan dengan dirinya. Padahal, Islam selalu memberikan kebebasan berbicara dan toleransi terhadap semua pemeluk agama dan berkeyakinan serta rasa hormat bagi umat manusia, tampa membeda-bedakan satu sama lain (Bakar, 2015). Perlu adanya perilaku toleran antarkelompok agar kehidupan bermasyarakat tetap harmonis.

Contoh nyata perilaku toleran antarkelompok adalah NU dan Muhammadiyah. Sebagai dua organisasi keagamaan terbesar, keberadaan Muhammadiyah dan Nahdlatul Ulama dalam sejarah Indonesia modern memang amat menarik. Sepanjang perjalanan kedua organisasi Islam terbesar ini, senantiasa diwarnai kooperasi, kompetisi, sekaligus konfrontasi atau konflik. Apalagi kedua organisasi ini memiliki landasan historis dan fundamentalis yang berbeda. Muhammadiyah diidentikkan sebagai kelompok modernis, sedangkan NU diidentikkan sebagai kelompok tradisionalis. NU dikenal sebagai organisasi Islam tradisionalis dan konservatif yang berbasis masyarakat desa dengan tingkat ekonomi menengah ke bawah, sedangkan Muhammadiyah dikenal sebagai organisasi Islam yang modernis-substansialis yang berbasis masyarakat perkotaan dengan tingkat ekonomi menengah ke atas.

Perbedaan-perbedaan yang terjadi antara NU dan Muhammadiyah ini tidak dicoba untuk disatukan. Prinsip yang dianut adalah perbedaan itu rahmah sehingga tidak perlu diseragamkan (Irfani, Alimi, \& Iswari, 2013). Hal yang harus dilakukan adalah merawat keberagaman tersebut melalui perilaku toleran. Tidak dapat dipungkiri bahwa adanya perbedaan pasti menimbulkan gesekan. Namun demikian, gesekan dan konflik ini tidak berakhir destruktif. Gesekan dan konflik akibat perbedaan akidah dan muamalah menjadi pendorong munculnya rasa toleransi antar-umat Islam. Kekuatan Islam bukan hanya terletak pada adanya kesatuan (unity) pada wilayah fundamental keagamaan, tetapi juga pada keragaman (diversity) kultural dalam wilayah historis dan sosiologis keagamaan umat Islam. Hal ini menjadi indikasi penting, Islam merupakan agama yang dapat berkembang pada semua kawasan yang punya keaneragaman kultural. Dalam konteks sejarah Islam di Indonesia, Kita tidak bisa membayangkan, kalau saja Muhammadiyah dan NU tidak muncul di Indonesia (Rofiah, 2017). Munculnya perbedaan prinsip antara NU dan Muhammadiyah menjadikan Islam di Indonesia terlatih menghadapi perbedaan yang muncul sehingga potensi konflik horizontal dapat diminimalisasi. Toleransi sebagai sebuah paradigma berada dalam posisi penting di tengahtengah tantangan dan konflik internal. Dengan demikian, dapat disimpulkan bahwa konsep toleransi tidak hanya berkaitan dengan masalah agama, tetapi keseluruhan aspek kehidupan (Rantesalu \& Iswanto, 2018).

Setelah Ibu, perilaku toleran dalam puisi karya siswa SMA Kabupaten Gresik ditujukan kepada sahabat. Bentuk toleransi kepada sahabat ini berupa menerima dan menghargai perbedaan serta terbuka pada orang lain. Hal ini mengindikasikan pemikiran kolektif oleh siswa SMA Kabupaten Gresik. Pemikiran kolektif yakni ketika momen individual berubah menjadi momen kebersamaan ketika dipersamakan oleh sebuah identitas (Robet, 2013). Hal inilah yang muncul pada puisi karya siswa SMA Kabupaten Gresik. Kesamaan usia dan tingkat berpikir memunculkan momen solidaritas. Hal ini tentu baik mengingat hakikat manusia adalah bersosialisasi. Hal ini berkontradiksi dengan perilaku individualistis. Perilaku individualistis menekankan tidak memerlukan bantuan orang lain dalam menjalani apapun (Pusposari, Saryono, Siswanto, \& Hasanah, 2019). Perilaku ini tentu mengingkari kodrat manusia sebagai makhluk sosial.

Temuan menarik pada penelitian ini adalah perilaku toleran ini tidak hanya ditujukan kepada manusia, melainkan juga kepada makhluk hidup lain. Terdapat data yang merepresentasikan perilaku toleran kepada hewan dan tumbuhan. Hal ini mengindikasikan bahwa pesan berperilaku toleran ini berlaku secara universal. Pesan yang ingin disampaikan melalui puisi tersebut bahwa berperilaku toleran kepada sesama manusia saja belum cukup. Diperlukan perilaku toleran kepada makhluk hidup lain juga. Hal ini karena manusia tidak dapat hidup sendiri dan berlepas tangan terhadap lingkungan. Diperlukan kesinambungan hubungan antara manusia dan alam agar menciptakan harmoni. Harmoni antara manusia dan alam ini penting karena harmoni antar-elemen menciptakan tatanan lingkungan yang harmonis (Ho \& Chan, 2009). Jika salah satu elemen mengabaikan harmoni hubungan ini, maka yang terjadi adalah ketidakseimbangan elemen dalam lingkungan yang bersifat merusak. 
Temuan ini juga menunjukkan bahwa sastra dapat berperan aktif dalam upaya pelestarian lingkungan. Sastra dapat dijadikan sebagai media untuk mengampanyekan kesadaran pentingnya kelestarian lingkungan. Kampanye melalui sastra ini efektif sebab sastra memiliki jangkauan pembaca yang luas. Puisi karya siswa SMA Kabupaten Gresik ini juga menunjukkan pentingnya peran manusia dalam menjaga lingkungan. Manusia sebagai makhluk sosial juga harus merasa terikat dengan unsurunsur alami yang mengelilinginya sehingga mereka terinspirasi untuk melestarikannya (Wirawan, 2019a). Isu pelestarian alam ini penting karena alam memiliki aspek kebermanfaatan tinggi terhadap kelangsungan hidup manusia (Farida, 2017). Kampanye pelestarian lingkungan dapat menjamin keberlanjutan kelestarian alam sehingga manusia tetap dapat mengambil manfaatnya.

Isu lingkungan pada karya sastra memang sedang menjadi isu hangat. Pada umumnya, pengarang mengangkat masalah lingkungan itu dituangkan dalam bentuk puisi. Tema yang diangkat mulai dari masalah lingkungan rumah tangga sampai dengan lingkungan negara (Septiningsih, 2015). Hal ini menunjukkan wujud kepedulian masyarakat terhadap lingkungan. Munculnya isu lingkungan melalui perilaku toleran terhadap binatang dan tumbuhan ini mencerminkan bahwa tema lingkungan dalam karya sastra - termasuk puisi-mulai menjadi tema yang digemari dalam proses pembuatan karya.

Pembahasan tentang toleransi tidak dapat dipisahkan dari pembahasan tentang multikulturalisme. Hal ini karena dalam perspektif Indonesia, toleransi memegang peranan penting dalam menjaga masyarakat Indonesia yang multietnis, multiagama, dan multibudaya. Multikulturalisme merupakan sebuah ideologi yang bertujuan untuk menciptakan kesetaraan dan kedamaian dalam hubungan bermasyarakat (Irhandayaningsih, 2012). Mengelola kemajemukan bukalah perkara yang mudah. Di suatu sisi, masyarakat sebagai salah satu komponen bangsa memelihara identitas dan memperjuangkan aspirasinya (Kamal, 2013). Pada sisi lain, mereka juga dituntut untuk memberi andil dalam rangka memelihara kerukunan dan keutuhan bangsa. Perilaku toleran dari masing-masing kelompok masyarakat sangat penting untuk menjamin harmoni tetap terjaga dalam masyarakat yang multikultural. Multikulturalisme menekankan keanekaragaman kebudayaan dalam kesederajatan (Suparlan, 2014). Kesederajatan dalam konsep multikulturalisme ini penting agar tidak ada masyarakat atau anggota masyarakat yang merasa superior maupun inferior. Seluruh masyarakat dalam konsep multikultural harus bersifat sejajar. Dalam hal inilah peran toleransi sangat penting. Masyarakat yang majemuk harus terus dipupuk dengan semangat toleransi sehingga kemajemukan yang menjadi ciri khas bangsa Indonesia menjadi aset, bukan menjadi penghalang dalam memajukan bangsa.

\section{SIMPULAN}

Representasi perilaku toleran dalam puisi karya siswa SMA Kabupaten Gresik meliputi menghargai orang lain, menerima dan menghargai perbedaan, bersikap terbuka terhadap orang lain, serta menerima perbedaan pendapat. Bentuk perilaku toleran yang paling banyak muncul dalam puisi karya siswa SMA Kabupaten Gresik adalah menghargai orang lain. Hal ini menunjukkan tingginya rasa menghargai orang lain dalam puisi karya siswa SMA Kabupaten Gresik. Perilaku menghargai orang lain dalam puisi karya siswa SMA Kabupaten Gresik banyak ditujukan kepada orang terdekat, yakni Ibu dan sahabat. Ibu merupakan tema favorit yang dipilih sebagai sumber inspirasi penulisan puisi. Ibu merupakan elemen utama dalam perkembangan anak. Sosok Ibu berperan penting dalam setiap fase kehidupan anak, mulai pra-kelahiran, kelahiran, masa bayi, anak-anak, remaja, hingga dewasa. Perilaku toleran dalam puisi juga ditujukan kepada sahabat. Perilaku toleran ini tidak hanya ditujukan kepada manusia, melainkan juga kepada makhluk hidup lain. Hal ini mengindikasikan bahwa pesan berperilaku toleran ini berlaku secara universal.

Saran terkait kajian ini ditujukan kepada peneliti selanjutnya dan pengajar sastra. Saran kepada peneliti lanjutan yakni penelitian berikutnya mengenai toleransi dalam karya sastra perlu terus dilakukan dan dikembangkan untuk mengetahui lebih lanjut tentang perilaku toleran yang terdapat dalam karya sastra, baik berupa novel, cerpen, puisi, maupun naskah drama. Hal ini perlu dilakukan untuk menunjukkan bahwa sastra tidak dapat dipisahkan dari masyarakat dan dapat menjadi cerminan kehidupan masyarakat sekaligus menunjukkan sumbangsih dunia sastra terhadap kehidupan masyarakat. Saran kepada pengajar sastra yakni penelitian ini dapat memberikan informasi berharga bagi pengajar sastra. Isi penelitian berupa representasi perilaku sosial dalam puisi dapat dijadikan bahan pengajaran sastra sebagai perspektif baru dalam mengkaji karya sastra. Hasil kajian ini juga dapat digunakan untuk menanamkan nilai-nilai sosial melalui karya sastra, sebagai bekal untuk interaksi dalam lingkungan sosial karena karya sastra pada dasarnya merupakan cerminan perilaku masyarakat.

\section{DAFTAR RUJUKAN}

Arifin, B. (2016). Implikasi Prinsip Tasamuh (Toleransi) Dalam Interaksi Antar Umat Beragama. Fikri, 1(2), 391-420.

Bakar, A. (2015). Konsep Toleransi dan Kebebasan Beragama. Toleransi, 7(2), 123-131.

Creswell, J. W. (2009). Research Design: Qualitative, Quantitative and Mixed Approaches ( $3^{\text {rd }}$ Edition). In Research Design: Qualitative, Quantitative, and Mixed Methods Approaches.

Efendi, D. (1994). Kemusliman dan Kemajemukan. In T. Sumatrana (Ed.), Dialog: Kritik dan Identitas Agama. Yogyakarta: Dian-Interfidel.

Endraswara, S. (2011). Metodologi Penelitian Sosiologi Sastra. Yogyakarta: CAPs.

Farida, D. N. (2017). Kritik Ekologi Sastra Puisi Perempuan Lereng Gunung Karya Ika Permata Hati dalam Antologi Puisi Perempuan di Ujung Senja melalui Ekofeminisme Susan Griffin. BASINDO : Jurnal Kajian Bahasa, Sastra Indonesia, dan Pembelajarannya, 1(2), 48-52. https://doi.org/10.17977/um007v1i22017p048 
Ghazali, A. (2009). Argumen Pluralisme Agama: Membangun Toleransi Berbasis Al Quran. Depok: Katakita.

Hasanah, M. (2014). Karakteristik Struktural-Semiotik Puisi-Puisi Karya D. Zawawi Imron. Litera: Jurnal Penelitian Bahasa, Sastra, dan Pengajarannya, 12(2), 269-286. https://doi.org/10.21831/ltr.v12i02.1589

Ho, S. S. M., \& Chan, R. S. Y. (2009). Social harmony in Hong Kong: Level, Determinants and Policy Implications. Social Indicators Research, 31, 37-58. https://doi.org/10.1007/s11205-007-9152-0

Irfani, A. I., Alimi, M. Y., \& Iswari, R. (2013). Toleransi Antar Penganut Nahdhatul Ulama, Muhammadiyah, dan Kristen Jawa di Batang. Komunitas: International Journal of Indonesian Society and Culture, 5(1), 1-13. https://doi.org/10.15294/komunitas.v5i1.2366

Irhandayaningsih, A. (2012). Kajian Filosofis terhadap Multikulturalisme Indonesia. Humanika, 15(9), 1-8.

Kamal, M. (2013). Pendidikan Multikultural bagi Masyarakat Indonesia yang Majemuk. Jurnal AL-Ta'Lim, 1(6), 451-458.

Mabruri, Z. K., \& Sayuti, S. A. (2015). Potret Sosial Dalam Sepuluh Sajak Remy Sylado dan Relevansinya dengan Pembelajaran Sastra di SMA. LingTera, 2(1), 101-110. https://doi.org/10.21831/lt.v2i1.5412

Misrawi, Z. (2006). Toleransi Versus intoleransi. Harian KOMPAS, p. 6.

Pusposari, D., Saryono, D., Siswanto, W., \& Hasanah, M. (2019). Ande-Ande Lumut Folklore as the Builder of Youth Character. The International Journal of Social Sciences and Humanities Invention, 6(5), 5424-5429. https://doi.org/10.18535/ijsshi/v6i5.04

Rantesalu, M. B., \& Iswanto, I. (2018). Toleransi Berdasarkan Cerita Rakyat Tallu To Sala' Dadi di Toraja. BIA': Jurnal Teologi dan Pendidikan Kristen Kontekstual, 1(1), 13-25.

Ratna, N. K. (2012). Antropologi Sastra: Penggunaan Teori dan Metode secara Eklektik dan Metodologi Campuran. Pustaka, 12(1), 52-64.

Robet, R. (2013). Altruisme, Solidaritas dan Kebijakan Sosial. Jurnal Sosiologi Masyarakat, 18(1), 1-18.

Rofiah, K. (2017). Dinamika Relasi Muhammadiyah dan NU Dalam Perspektif Teori Konflik Fungsional Lewis A. Coser. KALAM, 10(2), 469-490. https://doi.org/10.24042/klm.v10i2.10

Septiningsih, L. (2015). Kepedulian Lingkungan Dalam Jamangilak Tak Pernah Menangis. ATAVISME, 18(1), 63-74. https://doi.org/10.24257/atavisme.v18i1.33.63-74

Sumiyardana, K. (2018). Kesesuaian Masyarakat Jawa Dalam Novel Mantra Pejinak Ular dengan Realita: Analisis Sosiologi Sastra. Madah: Jurnal Bahasa dan Sastra, 8(2), 210-222. https://doi.org/10.31503/madah.v8i2.499

Suparlan, P. (2014). Menuju Masyarakat Indonesia yang Multikultural. Antropologi Indonesia. https://doi.org/10.7454/ai.v0i69.3448

Teeuw, A. (2013). Sastra dan Ilmu Sastra. Bandung: Pustaka Jaya.

Tjahjono, T. (2011). Mendaki Gunung Puisi. Malang: Bayumedia.

Tjahjono, T. (2012). Melawan Kekuasaan Dengan Puisi. ATAVISME, 15(1), 49-58. https://doi.org/10.24257/atavisme.v15i1.47.49-58

Wilson, A., \& Dymoke, S. (2017). Towards A Model of Poetry Writing Development as a Socially Contextualised Process. Journal of Writing Research. https://doi.org/10.17239/jowr-2017.09.02.02

Wirawan, A. K. (2019a). Cultural Ecological Values in Orang-Orang Proyek Novel By Ahmad Tohari As An Environmental Conservation Medium. ISLLAC : Journal of Intensive Studies on Language, Literature, Art, and Culture. https://doi.org/10.17977/um006v3i12019p082

Wirawan, A. K. (2019b). Metode ATM (Amati, Tulis, Modifikasi) untuk Pembelajaran Menulis Puisi Berwawasan Lingkungan. Hasta Wiyata, 2(1), 1-10. https://doi.org/10.21776/ub.hastawiyata.2018.002.01.04

Yasir, M. (2014). Makna Toleransi Dalam Al-Qur'an. Jurnal Ushuluddin, 22(2), 170-180. https://doi.org/http://dx.doi.org/10.24014/jush.v22i2.734 